\title{
THE COVER OF THE FIRST EDITION OF LEAVES OF GRASS
}

\author{
Matt Miller
}

Throughout His Life, Walt Whitman demonstrated a keen understanding of the importance of first impressions. With his combined experience as a both a newspaper editor, where visual presentation of text is an essential component of financial success, and a printer thoroughly familiar with the technical aspects of book-making, it should be no surprise that Whitman took some novel measures in representing himself to readers before they opened his books: from his infamous use of Emerson's quote on the spine of the second edition, to the butterfly motif he announced with the blind-stamped image on the third, to the variously-colored bindings of this and post Civil-War editions that had symbolic resonance with the state of his country, himself, and his work. For better or worse, Whitman knew, we do judge books by their covers, and no other American author has gone to such lengths to encode his ideas in his books' physical appearance.

Whitman's cover design for the first edition of Leaves is no exception. In addition to the book's unusual size and shape - and the fact that he chose to leave his name off of the cover and spine-Whitman used unique, hand-drawn gold-stamped lettering to portray his book's title to potential audiences. Although we don't know for certain who drew this design, it is usually assumed to have been Whitman himself. It fits with his way of working - taking control of book production to the greatest extent possible - and we know for sure that he drew the font design for the spine of the second edition, because he left behind a drawing modeling these letters, an image of which was published in Joel Myerson's 1993 bibliography. ${ }^{1}$ We don't have such concrete evidence that Whitman himself sketched out the lettering for the first edition, yet what we know about him suggests that he would have. At the very least, we can be sure that he approved of it, and that like so much else about this extraordinary volume, it's a gesture pregnant with intention and significance. So the question arises: what was Whitman trying to portray for us with these thirteen plant-encrusted letters? (See Figure 1.)

The idea of cover lettering spelled from plants wasn't in itself unusual when the first Leaves of Grass was published. Typographers refer 
to the style as "floriated lettering," and it was a conventional approach for the time. Although it employed a very different style of floriated lettering, Fanny Fern's Fern Leaves from Fanny's Portfolio is Whitman's most famous predecessor in this regard. It was Whitman's execution of his floriated lettering that sets his design apart. It's unusual, for example, for such lettering to be comprised of multiple species of plants, and the ornate level of its detail is striking. It was also strange for such lettering to be so asymmetrical and even, as in the case of the central word, illegible. To viewers who hadn't seen the lettering on the spine, the book's title must have seemed like "Leaves . . something . . . Grass." Another unusual and striking detail is the root-like structures dangling beneath the letters, some of which might be shoots or tendrils, or perhaps the Spanish moss that Whitman must have encountered on his trip to New Orleans.

Previous readers have interpreted this lettering as being "rooted" in the book itself, suggesting a language emerging as naturally from the text as grass. Technically, however, this is incorrect: the letters on the cover don't seem to be language rooted in the cover of its book. Rather, the roots seem to be floating in air. The images are reminiscent of pictures from botany books and science textbooks, where we find live plants rendered as if planted in transparent soil. These kinds of presentations are motivated by the idea of scientific realism, but with Whitman's cover

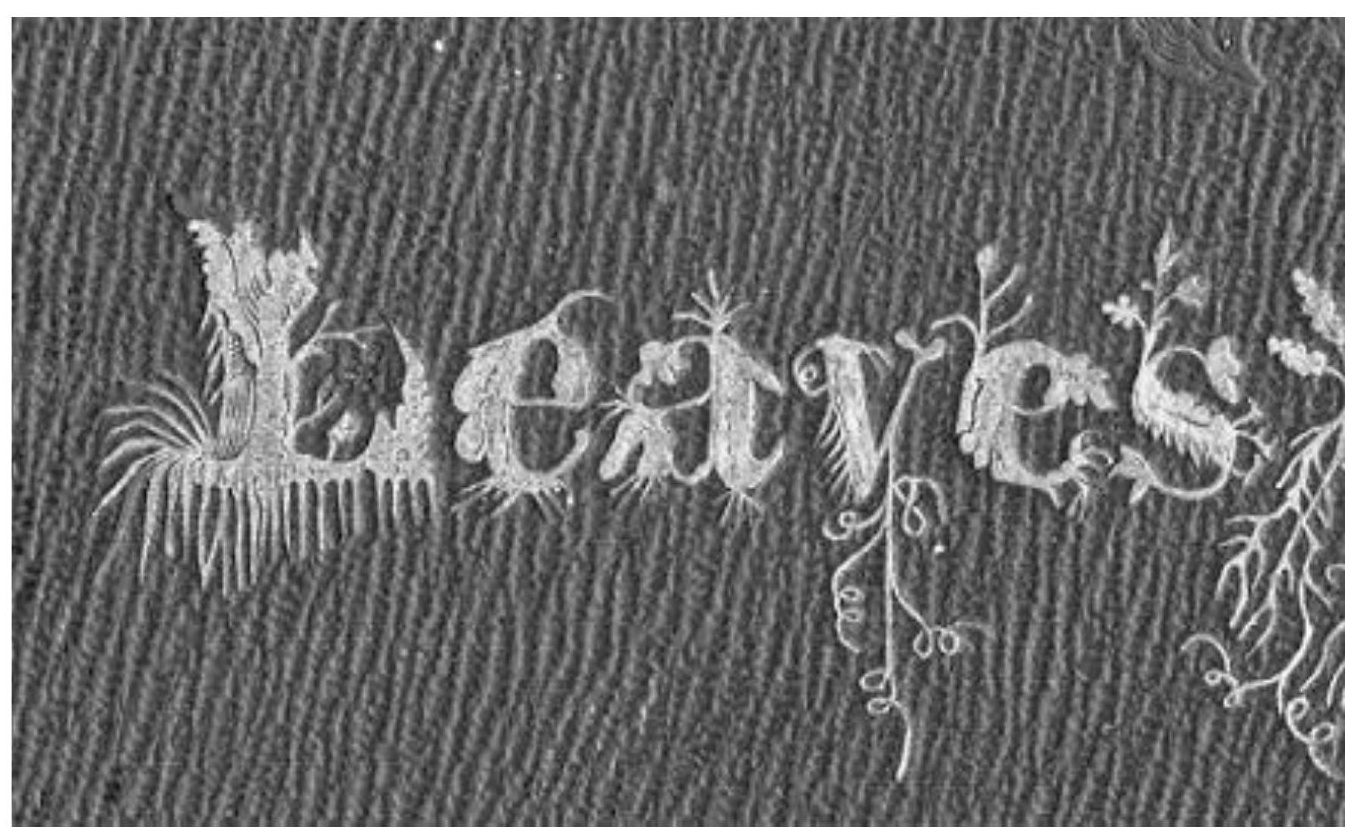

Figure 1. 
that's not the case. The letters seem to represent an amalgam of various realistic plant-features, but no one specific plant seems to be depicted. Diana Horton, a botanist at the University of Iowa, has noted, however, that some of these differing species - those adorning the "L," the "of," the "G," and the final "s"- do seem to share a fibrous monocot type of root system similar to the roots of various species of grass. ${ }^{2}$

So why did Whitman choose to include these unusual root-designs, and why did he portray them as floating on the cover of the book? It's easy enough to imagine these roots disappearing into the cover, so that the title would appear to be growing out of the text itself. That would portray an image of a kind of linguistic organicism: a book which gives seed to other words. While that is true of the effect of Leaves of Grass, that isn't the effect of the poet's cover design. Although Whitman does depict himself as emerging from his own book in his infamous frontispiece image, the letters on his cover do not. The first edition does present us with an image of a book creating Whitman - a poet growing out of his own text, made by one of his leaves - but we do not have an image of a book growing its own language.

Another unusual aspect of the book design of the first edition helps to illuminate the back-story of the cover's floriated lettering: the oddly large font chosen for the book's title page. The type shown here is a classic example of the Scotch Roman face, and the contents of the book are

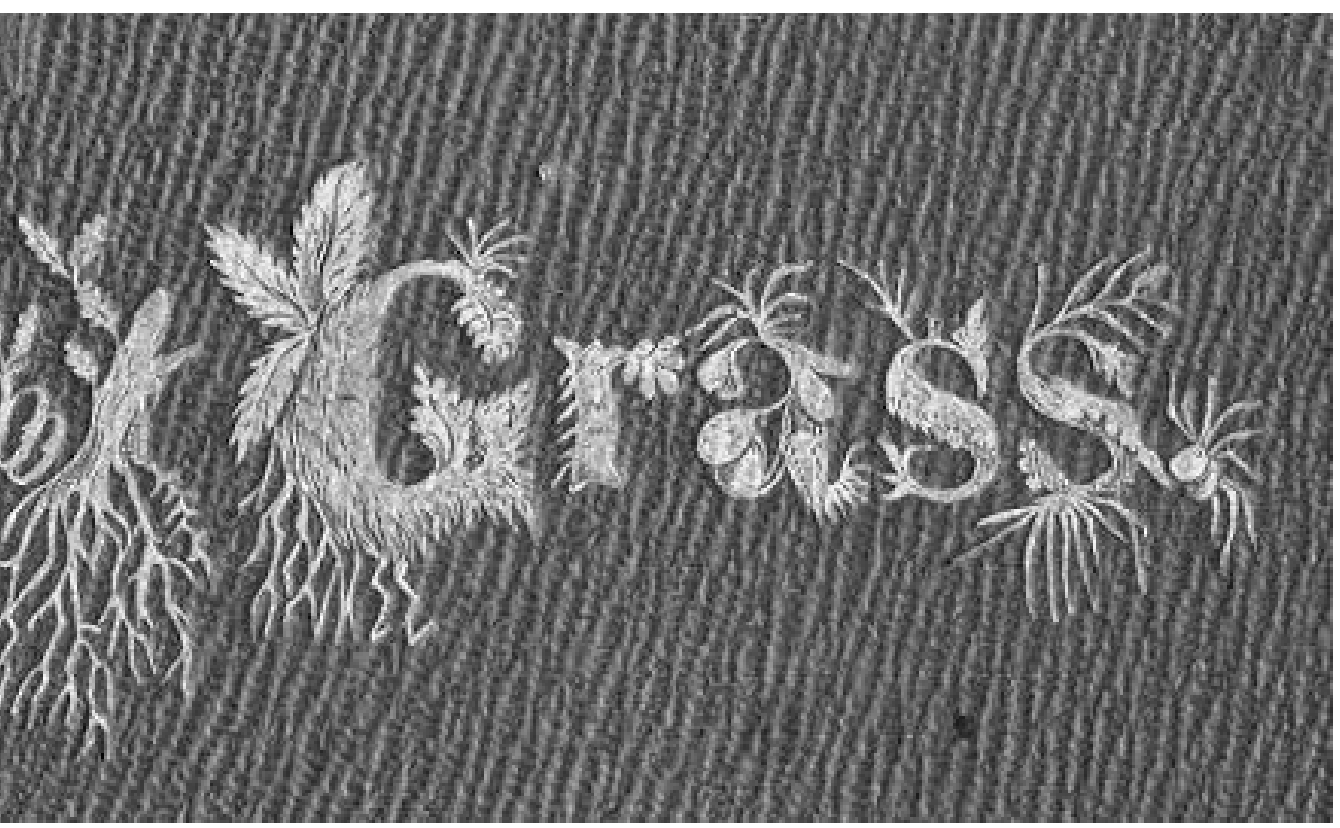


printed in this type as well. ${ }^{3}$ According to a book often referred to as the "bible of typography," Alexander Lawson's Anatomy of a Typeface, the term "Scotch face" was "first given to a type cut by [Alexander] Wilson and the S.N. Dickinson foundry in Boston about 1837." The actual design goes back further, and originates with a font called Pica Roman No. 2, which was first cut in 1809. Imitations of this font style were popular in United States throughout the 1820s, 1830s, and 1840s, and Whitman's font for the first edition of Leaves is one of them, a variant from the Bruce foundry in Williamsburgh. The oversized type of this title page would have been more commonly used for commercial rather than literary purposes. It represents a conventional face but also an unusually large choice of font (72-point for the word "Leaves" and 108 for "Grass"). With its boldness, hard-edged clarity, and commercial applicability, this type face seems a far cry from the lettering portrayed by Whitman on the cover, and the striking contrast between the living letters of the cover and "cold type" of the title page must have been intentional.

A close comparison of the title page font with the floriated lettering on the cover does, however, reveal a deeper connection (see back cover). A look at the cover and title page letters side-by-side shows that the cover letters are based on the same font from the title page. The letters' apertures are nearly identical, and although overgrown with foliage, both types of lettering display the same ball terminal at the end of the " $r$ " and the "s." The fat vertical right-side stroke of the capital "G" is paralleled in the plant-lettering, as is the crossbar and the "V"-shaped opening at the stroke's bottom. Also, we find the same exaggeration between thick and thin strokes in the lower case "s," the lower case " $\mathrm{v}$," as well as the "e" and "a." There is vegetation growing from the thin strokes of the cover lettering, but if you were to strip it away, it would be the same thin, elegant style of the letters on the title page.

This parallel between the cover and title page lettering helps us to understand why the "of" in the title is illegible. In imitating the title page design, Whitman rendered the "of" on the cover in a smaller scale, and in the botanical scenario portrayed on the cover, the letters of this "of"-because they are so much smaller than the rest-appear to be simply the first letters overcome by foliage. Notice the letters' slant as well. As the "o" especially makes clear, the "of" on the cover is based on an italic type, just like the "of" on the title page. Another parallel involves that curious blob of plant matter after the final letter "s," which is actually a period. Including a period at the end of the title was a common convention for title pages, but it wasn't for covers. Whitman himself didn't use periods at the ends of his titles on the covers of any subsequent editions of Leaves of Grass, though he did in all of his title pages right up until the 1881 edition, when the period vanishes. This isn't the first time Whitman made interesting use of a period at the end of a title. As Ed 
Folsom has noted in a recent monograph, Whitman added a tail to the period on the title page of the 1860 edition of Leaves of Grass, turning it into what appears to be sperm. ${ }^{4}$ The period on the cover of the 1855 edition is also symbolically generative, suggestive of botanical instead of human reproduction.

In addition to explaining why the "of" in "Leaves of Grass" is illegible on the cover, the parallel between the title-page font and the lettering on the cover helps explain another mystery: why the roots of the letters are presented ungrounded, floating in space on the cover. The plant life on this lettering isn't growing from the book; it is growing from the letters themselves. Beneath the foliage lies the more conventional and typographically uniform font of the title page, but fleecing it are various forms of plant life, transforming the font into organic material from the inside out. Whitman's strong opinions about language - and about American uses of it in particular - help explain why he gave these letters roots in the first place: had he presented the letters without them, he would have presented language cut off from its source, a rootless language that can no longer grow, a form of language analogous to how Whitman saw the poetry that preceded him in the United States: rooted in conventions from Europe, it was a poetry cut off from its own soil.

It doesn't seem unreasonable that Whitman, basing his design on a typeface that originated in Europe, wanted to depict the letters as being transformed into something alive and indigenous to where they are found - that he wanted to depict a natural and, as he liked to phrase it, "autochthonic" portrayal of language in line with the views described in his various notebooks. He certainly knew the name of this type of font, as his notes regarding the typefaces of the 1860 edition demonstrate. ${ }^{5}$ The Scotch Roman face possessed a title that referred to two distinct European heritages. So it might have been especially tempting for Whitman to portray this font as being transformed by its living surroundings. The design suggests a language reborn in its new climate - and a literature reborn in the newly-established nation of its writers.

If we look at the foliation as emerging from the font itself, as opposed to its emerging from the cover of the book, the symbolism of the lettering shifts. A book that sprouts its own title on its cover presents itself symbolically as a generative, organic entity. But if it is the font of the book that is sprouting and growing, then the emphasis shifts toward language itself, as opposed to the artifact of the book. It suggests a language that starts as the kind of "cold type" that Whitman elsewhere says "chilled" him, and which the poet transforms into something vital and living. ${ }^{6}$ And the fact that the roots of this language float suspended on the book suggests that they will take root elsewhere-perhaps in the hearts and souls of their readers. Such an outlook parallels the spermatic symbolism of the title page font of the 1860 edition, where the spermatic 
rendering seems to suggest that his words are intended to impregnate his readers' imaginations.

Another noteworthy feature of the floriated gold-stamp lettering is that none of the letters touch each other in any way. Despite their highly ornate vegetation, which sprouts in all directions and sends out shoots and roots that are longer than the letters themselves, Whitman was careful to ensure that not a single point of contact existed. They are ultimately unique and independent entities, thriving in close proximity to their neighbors but self-reliant and autonomous in structure and presentation. This portrayal of a combination of independence and living harmony is reminiscent of his vision of democracy, a vision which starts with the isolated self - a self that remains independent and egotistically unique-but which though the course of his book dilates to include others in a larger totality.

Another implication relates to an observation noted previously: the fact that there are a number of species of plants represented by these letters (even if the species themselves are fanciful). The variety of planttypes used in the gold-stamp lettering depicts a unity in diversity with revealing implications. On the one hand, this portrayal also relates to his visionary democracy and the evolving dream of American integration. The symbolism resonates with his antebellum optimism about his country's destiny. As I have suggested, however, the direct symbolism of this lettering is as a representation of language, and the resonance in this regard is equally rich. As his notes from around this period indicate, Whitman delighted in the idea of American English as an inclusive and absorptive medium. He loved bringing together words of disparate origins, as is demonstrated by his infamous use of foreign language terms in his poems. This fascination with bringing disparate parts into a whole is strikingly revealed in the poet's approach to the language in his notebooks, and this representation is suggestive of the creative process Whitman was engaged in when the lettering was designed. Just as his title lettering brings together different species of plants, Whitman's notebooks and manuscript drafts reveal how he brought together different specimens of discourse in his poems. From descriptions of erotic encounters, to language collaged from history and science books, stolen from newspaper accounts, old notebooks, speeches, and numerous other sources, Whitman brought together phrases and sentences to form the "collage of himself" that is Leaves of Grass.

Although a thorough assessment of Whitman's collage-like creative practices is beyond the scope of this essay, there is a particularly striking example of Whitman's writing process that helps us to understand the poet's representation of language on the cover of the first edition. In one important pre-1855 notebook, we find Whitman repeatedly going over material that later became the fourth poem in the first edition of 
Leaves, the poem later known as "The Sleepers."The notebook contains a wealth of fascinating early material, and one passage is particularly revealing. Consider this passage from which Whitman later extracted material that became lines 36-38 of the untitled fourth poem from the 1855 edition of Leaves:

\section{The Poet}

I think ten million supple ${ }_{\wedge}^{- \text {fingered }}$ gods are perpetually employed hiding beauty in the world - hiding burying it everywhere in every thing — but and most of all where in spots that men and women do not think of it, and never look - as in death, and [itlegible] poverty and wickedness. - cache [illegible] ${ }_{A}^{\text {after }}$ [and?] cache again - they is-all over the

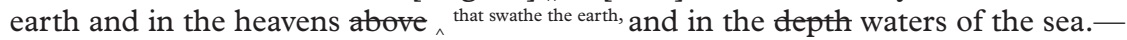
Their They do their task jobs well; those supple-fingered gods. journeymen divine.

[page break]

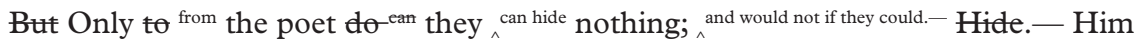
they attend wait on night and day and show where they take, uncover all, that he shall see the naked breast and the most private of Delight. ${ }^{7}$

Here we find a type of discourse that is frequently apparent in notebooks composed around the same time as this one: a prose declaration of what it means to be a poet. A variation on some of Emerson's descriptions in his own essay of the same title, Whitman's view of his role is familiar. The poet is the visionary who sees through the world's drab exteriors to hidden wellsprings of sensual delight. More erotic than Emerson, the poet's insight into hidden beauty is described as an erotic disrobing, and in a metaphoric striptease, Whitman's "journeymen divine" undress worldly delight for his gaze. However, at the end of this passage the manuscript becomes less clear and more tantalizing. At just the moment when the "naked breast" is revealed and we are to see the "most private" aspect of delight, Whitman leaves a gap in the text and frustrates his own unveiling. The question that lingers is what precisely is this unnamed representation of "Delight" that the poet's vision strips down.

The only critic to have described this passage thus far, James Perrin Warren, presents his transcriptions of the notebook in a selectivelyedited form that doesn't acknowledge Whitman's cross-outs and other manuscript clues about the gender of his objects of affection. He unambiguously asserts that what Whitman's "gods" uncover is the "figure of the naked female." 8 However, another manuscript leaf separate from this notebook leaves little room for doubt that the blank space in the phrase "most private of delight" was not, in Whitman's mind, occupied by female anatomy. Perhaps because the leaf is a part of the Trent Collection at Duke University-whereas the "efflux of the soul" notebook is a part of the Harned Collection in Washington, D.C.- these 
two manuscripts have not been previously associated (see Figure 2.) One side of the Trent manuscript shows Whitman drafting lines later adapted for the poem eventually called "Song of Myself," and the other is divided into columns on the top half. In the left-hand column, we find Whitman listing a series of suggestive phrases: "Sweet flag / Sweet fern / illuminated face / clarified / unpolluted / flour-corn / aromatic / Calamus / sweet-green / bulb / and melons with / bulbs swee grateful / to the hand." The phrase "sweet flag" faintly echoes Whitman's "pennants of joy" from "The Sleepers," though "sweet flag" is also a colloquial expression for the hardy grass known as calamus, and this is likely Whitman's primary meaning here. Although in hindsight we know that Whitman later used "Calamus" as a title for his cluster of poems about same-sex love, here this might be a list of words associated with plant parts, and we have to squint to see any sexual implications so far.

Some writing below this list suggests the "bulbs" aren't those of plants: "bulbous bulbous / Living bulbs, melons with polished rinds the [illegible] ${ }^{\text {that }}$ soothing the hand to touch smooth to the [illegible] reached hand / Bulbs of life-lilies, polished melons [illegible] ${ }^{\text {flashed }}$ for the gentlest mildest hand that shall reach." These "bulbs" seem more like metaphors for testicles, and there is little doubt what Whitman means by "life-lilies." The phallic connotation is clinched by some writing above and to the right of this passage:

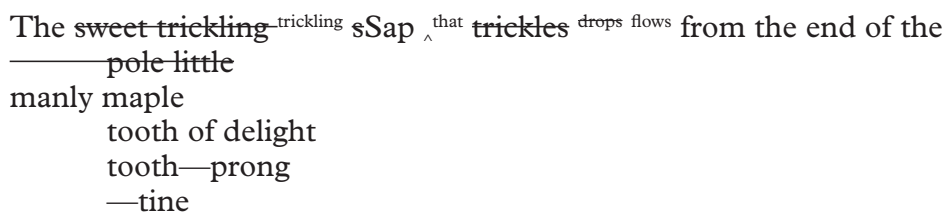

spendt spend ${ }^{9}$

This manuscript leaf is suggestive in its own right, demonstrating, among other things, that Whitman associated "calamus" with male sexuality long before he published his group of poems under that title in the 1860 Leaves. But it also shows how here, where we find Whitman experimenting with imagery to represent the ejaculating penis, we also find him completing the blank left in the passage: "most private of delight." The association between his manuscript blank "of delight" and his "tooth of delight" is strengthened in juxtaposition with these lines from the published poem:

The cloth laps a first sweet eating and drinking,

Laps life-swelling yolks . . . laps ear of rose-corn, milky and just ripened:

The white teeth stay, and the boss-tooth advances in darkness,

And liquor is spilled on lips and bosoms by touching glasses, and the best liquor after- 
Sweet flag Inect fern Mrminates fuce clarifies

inpollutes flam $=\cos$. Galamns Lreat = gum

buen aro melous witt bulbs sratefuc:
Iav a look mpstic in a trance esealatiovi

somets will and untamed half samase

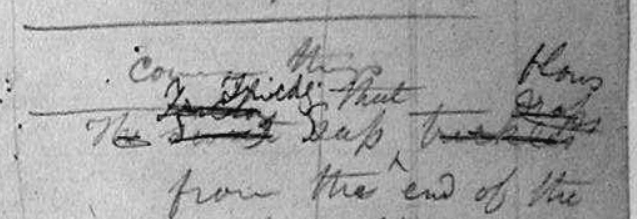

from the eno of the manb mapec tht tooth of sockte tooth-prons spent rpem bultans
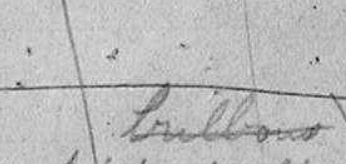
bulls, pnelows with fichater mir

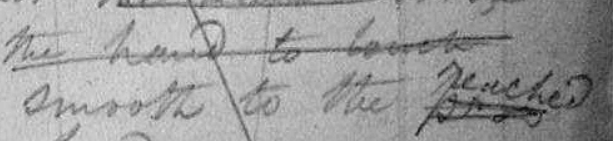

Rults Kaw likis, mest melowly shale unod

Figure 2. Whitman's “Sweet Flag” manuscript. Trent Collection, Duke University.

93 
ward. ${ }^{10}$

Robert K. Martin was Whitman's first reader to acknowledge that this passage describes oral sex, and the manuscripts confirm this criticallybelated honesty. ${ }^{11}$ These drafts suggest that as early as 1854 - and perhaps earlier-Whitman was keenly aware of and struggling to express homosexual eroticism in his poems; in addition, it is clear that he was sensitive to how readers would receive this eroticism, and he succeeded in rendering it with enough ambiguity to evade readers unready to deal with his sexuality.

Just as Whitman's Scotch Roman face title-page font becomes disguised by his sprouting foliage, in the manuscript just discussed Whitman disguises his blatant sexual intentions in sprouting vegetal metaphor. Whitman's "flour-corn" from the manuscript reappears in the published version as the highly phallic "rose-corn, milky and just ripened." Whitman never used the phrase "tooth of delight" in "The Sleepers." Instead, his bluntly sexual "tooth of delight" was half-hidden in the less blatant "boss-tooth." As metaphor, Whitman's "tooth" covers for the phallus, and more subtly, Whitman uses double meanings in his locution to intentionally allow two distinct interpretations.

One such doubling is in Whitman's use of the word "lap." The dictionary that Whitman himself used while composing these poems shows two competing meanings: on the one hand, for a cloth to lap is for it to swathe or enfold, so the line "the cloth laps a first sweet eating and drinking" could simply mean that clothing covers up the physical source of sexual pleasure, but with his repetitions of the word in the next line, the word "lap" begins to suggest its common meaning as to "lap up" or lick "life-swelling yolks . . . . ear of rose-corn, milky and just ripened." 12 It's hard for contemporary readers to avoid hearing a description of what Martin describes as "the act known politely as fellatio."Yet in the other sense of the word "lap," "yolks" could be construed as a metonym for the womb, so that the line could be taken to mean that cloth covers both the male and female genitals. Whitman's double meaning here permits readers compelled to maintain a heterosexual reading of the line to do so, and for readers ready to hear the other, more biographically-significant meaning, the image is quite clear.

In Whitman's "tooth of delight" and his lines that follow the ones just described, another nuanced double-reading unfolds from the poet's careful choice of words. In the dictionary Whitman owned and likely consulted while composing these poems, the primary definition of "boss" reads as follows:

1. A stud or knob; a protuberant ornament, of silver, ivory, or other material, used on bridles, harnesses, \&c.

-A protuberant part; a prominence; as, the boss, of a buckler. 
Though the word didn't signify the same broadly-conceived social role that it does today, a similar nascent definition for the contemporary meaning of "boss" had recently arisen in the United States. It is listed as the secondary definition for the word in Whitman's dictionary: "Among mechanics, the master-workman or superintendent. [This word originated among the Dutch settlers of New York, but is now used extensively in the other States.]" "Boss" then, in the sense we think of it, was a new coinage that had only recently spread from where it originated in New York to the rest of the country. Coming from his very home and from the Dutch settlers among which his mother could count herself a member, this slangy definition of "boss" must have appealed to Whitman, and he uses it in this colloquial context the first time it comes up in "The Sleepers" when he says "Only from me can they hide nothing and would not if they could; / I reckon I am their boss, and they make me a pet besides." "13 However, the second time Whitman uses the word-in its more explicitly phallic presentation - the poet surely had in mind the primary definition. He must have known that most Americans would have understood the word in terms of its then more common usage as "a protuberant part; a prominence." It seems likely that when many readers today hear the line "The white teeth stay, and the boss-tooth advances in darkness," they interpret the boss-tooth as one among the other "white teeth" - that is to say, their leader - and the line probably has an absurd and even humorous effect, especially if it is read in a sexual light. From this point of view, the line can be taken to present an orgiastic scene in which the boss penis advances from the other penises, and it is this reading that has allowed critics to interpret the passage - if they mentioned its blatant sexuality at all - from a heterosexual point of view. The "boss tooth" advances from the gay gang of blackguards to have sex with the passive woman. The colloquial ring of "boss" and the odd metaphor of the phallus as protruding "tooth" temper the image's potentially aggressive implications and present the scene in an ambiguously comic light. With this humorous depiction of the penis as "boss tooth," he seems to be poking fun at normative, male sexual fantasies.

Whitman, who had the representation of his own lapped penis enlarged in successive versions of the frontispiece to the first edition of Leaves, was surely aware of this possible reading. ${ }^{14}$ The care with which he worked over the passages leading up to these lines in his manuscripts suggests an intense self-awareness of the connotations his sexual imagery could evoke. Whitman knew that if he were to attract the audience he craved, it would be necessary for him to allow readers to see these lines in a heterosexual light. However, when we look at the phrase "boss-tooth" in terms of the primary definition of the word "boss" as a "protuberance," an alternate, more biographically salient reading becomes apparent: the "boss-tooth" is not being presented as one among the other "white teeth." 
It is being presented in contrast to those teeth: the "white teeth" are the teeth in one's mouth, and the "boss tooth"- the "protuberance," the "tooth of delight" - is the only penis in the image. In other words, the "white teeth stay" back as the "boss-tooth advances" into the "darkness" of the mouth. Although Martin seems not to have been aware of these manuscripts or of the definition of boss from Whitman's dictionary, they confirm his groundbreaking reading of the poem.

In the "boss-tooth" image, then, Whitman skillfully walks the line between extraordinary, culturally-transgressive homosexual candor and an equally extraordinary but not-quite-so-transgressive heterosexual allowance. Just as his cover presents a floriated font grown over his Scotch Roman face type, his doubling of meaning by way of careful diction and ambiguous metaphor presents a heterosexual reading imposed over the starker same-sex interpretation. Whitman chooses the phrases that form the published versions of these passages from multiple sources and from specimens (or shall we say species) of discourse in his notebooks. Just as different plant-types are gathered to form a disparate, yet ultimately cogent expression in his floriated lettering, different uses of language in his notebooks are pulled together to form cogent expression in his lines. The sexually-inflected imagination apparent in the "Sleepers" passage is also reflected in the foliage on the cover, which is itself distinctly sexual, stylized into bulbous protrusions fleecing the letters and overflowing with generative fecundity. I do not mean to suggest that Whitman's cover design is intended to directly relate to these particular lines, but it does reflect the attitude toward language and sexuality that engenders them. By lapping meaning in double-edged diction and metaphor, Whitman presents a sexually-charged but indeterminately-gendered subjectivity that allows audiences of varying sexual orientation to project their own desires and come away with satisfying readings.

The University of Iowa

\section{NOTES}

1 Joel Myerson. Walt Whitman: A Descriptive Bibliography (Pittsburgh: University of Pittsburgh Press, 1993), 27.

2 Diana Horton (botanist, University of Iowa), personal interview, October 25, 2005.

3 John Downer (font historian and designer, Iowa City), telephone interview, October 26. Confirmed by comparison with examples of the Scotch Roman face from Alexander 
S. Lawson, Anatomy of a Typeface (Boston: Godine, 1990).

4 Ed Folsom, Whitman Making Books / Books Making Whitman: A Catalog and Commentary (Iowa City: Obermann Center for Advanced Studies, 2005), 19.

5 See, for example, Whitman's "English Runic" notebook in Edward F. Grier, ed., Notebooks and Unpublished Prose Manuscripts (New York: New York University Press, 1984), 419-429.

6 The following lines from the second poem of the first edition of Leaves of Grass (eventually titled "A Song for Occupations") were excised from the poem in 1881:

Come closer to me,

Push close my lovers and take the best that I possess,

Yield closer and closer and give me the best you possess.

This is unfinished business with me ... how is it with you?

I was chilled with the cold types and cylinder and wet paper between us.

Leaves of Grass (Brooklyn, New York: 1855), 57. A facsimile of the first edition is available on the Whitman Archive (www.whitmanarchive.org).

7 This notebook is transcribed in by William White in Whitman's Daybooks and Notebooks (New York: New York University Press, 1978), 3:764-770; the passage I focus on is on p. 770. I have used my own transcription from the original notebook.

8 "'Catching the Sign': Catalogue Rhetoric in 'The Sleepers,"” Walt Whitman Quarterly Review 5 (Fall 1987), 22.

9 This passage is transcribed in Notebooks and Unpublished Prose Manuscripts, 194; I have used my own transcription from the original manuscript.

10 Leaves of Grass (1855), 72.

11 The Homosexual Tradition in American Poetry (Iowa City: University of Iowa Press, 1998), 11.

12 Whitman owned copies of both Webster's and Worcester's competing dictionaries, but he preferred Webster's American Dictionary of the English Language; I've used the 1848 edition of this dictionary here. See Ed Folsom, "Dictionaries," in J. R. LeMaster and Donald D. Kummings, eds., Walt Whitman: An Encyclopedia (New York: Garland, 1998), 183-184.

\section{Leaves of Grass (1855), 71.}

14 Ted Genoways explores the changing frontispiece in "'One goodshaped and wellhung man': Accentuated Sexuality and the Uncertain Authorship of the Frontispiece to the 1855 Edition of Leaves of Grass," in Susan Belasco, Ed Folsom, and Kenneth M. Price, eds., Leaves of Grass:The Sesquicentennial Essays (Lincoln: University of Nebraska Press, forthcoming). 